\title{
Oligonucleotide Fingerprinting Using Simple Repeat Motifs: A Convenient, Ubiquitously Applicable Method to Detect Hypervariability for Multiple Purposes
}

J. T. Epplen ${ }^{\mathrm{a}}$, H. Ammera, C. Epplen ${ }^{\mathrm{a}}$, C. Kammerbauera , R. Mitreitera, L. Roewer ${ }^{a}$, W. Schwaiger ${ }^{a}$, V. Steimle ${ }^{a}$, H. Zischler ${ }^{a}$, E. Albert, A. Andreas ${ }^{b}$, B. Beyermann ${ }^{c}$, W. Meyer ${ }^{c}$ J. Buitkamp ${ }^{d}$, I. Nanda ${ }^{e}$, M. Schmide, P. Nürnbergf , S. D. J. Pena ${ }^{\mathrm{g}}$, H. Pöche ${ }^{\mathrm{h}}$, W. Sprecher M. Schartlj, K. Weising ${ }^{k}$ and A. Yassouridis ${ }^{1}$

${ }^{a}$ Max-Planck-Institute for Psychiatry, W-8033 Martinsried, Germany; 'Kinderpoliklinik University, W-8000 München, Germany; 'Biology Section Humboldt University, 0-1040 Berlin, Germany; 'Institute for Animal Husbandry and Breeding, Hohenheim University, W-7000 Stuttgart, Germany; 'Human Genetics Institute University, W-8700 Würzburg, Germany; 'Medical Genetics Institute Humboldt University (Charité), 0-1040 Berlin, Germany; ${ }^{8}$ Biochemistry Department, Federal University Minas Gerais, 30161 Belo Horizonte, Brazil; "Institute for Legal Medicine Free University, W-1000 Berlin, Germany; 'Institute for Legal Medicine University, W-3400 Göttingen, Germany; 'Gene Center, W-8033 Martinsried, FRG; 'Plant Molecular Biology Group, Institute for Botany University, W-6000 Frankfurt, Germany; 'Max-PlanckInstitute for Psychiatry, W-8000 Munich, Germany

\section{Summary}

A panel of simple repetitive oligonucleotide probes bas been designed and tested for multilocus DNA fingerprinting in some 200 fungal, plant and animal species as well as man. To date at least one of the probes has been found to be informative in each species. The human genome, however, has been the major target of many fingerprinting studies. Using the probe $(\mathrm{CAC})_{5}$ or $(\mathrm{GTG})_{5}$, individualization of all humans is possible except for monozygotic twins. Paternity analyses are now performed on a routine basis by the use of multilocus fingerprints, including also cases of deficiency, i.e. where one of the parents is not available for analysis. In forensic science stain analysis is feasible in all tissue remains containing nucleated cells. Depending on the degree of DNA degradation a variety of oligonucleotides are informative, and they have been proven useful in actual case work. Advantages in comparison to other methods including enzymatic DNA amplification techniques (PCR) are evident. Fingerprint patterns of tumors may be changed due to the gain or loss of chromosomes and/or intrachromosomal deletion and amplification events. Locus-specific probes were isolated from the human $(\mathrm{CAC})_{5} /(\mathrm{GTG})_{5}$ fingerprint with a varying degree of informativeness (monomorphic versus truly hypervariable markers). The feasibility of three different approaches. for the isolation of hypervariable mono-locus probes was evaluated. Finally, one particular mixed simple $(\mathrm{gt})_{\mathrm{n}}(\mathrm{ga})_{\mathrm{m}}$ repeat locus in the second intron of the HLA-DRB genes has been scrutinized to allow comparison of the extent of exon-encoded (protein-) polymorphisms versus intronic hypervariability of simple repeats: adjacent to a single gene sequence (e.g. HLA-DRB1*0401) many different length alleles were found. Group-specific structures of basic repeats were identified within the evolutionarily related DRB alleles. As a further application it is suggested here that due to the ubiquitous interspersion of their targets, short probes for simple repeat sequences are especially useful tools for ordering genomic cosmid, yeast artificial chromosome and phage banks. 
Oligonucleotides Specific for Simple Repeat Motifs are Informative for all Species Tested So Far in the Fungal, Plant and Animal Kingdoms

The existence of repetitive DNA sequences in eukaryotic genomes has been known for more than two decades (Britten and Kohne, 1968). Even after all these years of intense experimentation and scholastic reflection the raison d'être of most repetitive elements in the eukaryotic genomes remains elusive. Particularly with respect to the generation and/or maintenance of the class of tandemly organized simple repeat motifs, a coherent or thoroughly convincing concept is lacking. This failure is certainly also due to the fact that these elements exert in almost all cases no sequence-dependent function whatsoever (for a discussion see Epplen, 1988). Bearing this primary shortcoming in mind, simple sequences are evaluated here exclusively as a tool.

In hindsight the design and testing of simple repetitive oligonucleotide probes for DNA profiling could and should have been initiated as early as 1981/82. By then it was already clear that cloned simple repetitive (gata) $)_{n}$ and (gaca) $)_{m}$ sequences showed extensive restriction fragment length polymorphisms (RFLP's), e.g. among human individuals (Epplen et al., 1982). Meanwhile Alec Jeffreys and coworkers (1985a, b) have described the "minisatellites" and have established the whole concept of DNA profiling. Finally, in 1986 Ali et al. reported on initial successful efforts to differentiate human genomes using (GATA) ${ }_{4}$ and (GACA $)_{4}$ as well as other sequentially related simple quadruplet repeat (sqr) oligonucleotides. Additional probes harboring basic repeat motifs of two to six nucleotides were subsequently synthesized and hybridized to DNAs from a variety of sources (Arnemann et al., 1989; Beyermann et al., in press; Buitkamp et al., 1990, 1991; Epplen, 1988; Epplen et al., 1988, 1989; Nanda et al., 1988, 1990a, 1988b, in press; Vogel et al., 1988; Weising et al., 1989, 1990, 1991 (Fig. 1)).

The mere presence and quantity of these simple tandem repeats in the genome can be assessed by a convenient slot-blot hybridization method (Epplen, 1988). This, however, does not in itself prove the suitability of a given probe for DNA fingerprinting. The latter has to be investigated with restriction enzyme digested and electrophoretically separated DNA of the respective species. Even though it is best to start out on the basis of previous experiences using, for example (GGAT) ${ }_{4}$ for individualization in a novel fish species, the principle of trial and error has to be adopted. Table 1 lists the panel of oligonucleotide probes that have been chemically synthesized for DNA profiling. In common to all the probes are simple repeat motifs of $2-6$ bases. The total lengths range from 15 to 24 bases thus allowing the calculation of hybridization and stringent wash temperatures according to the formula $T_{m}\left({ }^{\circ} \mathrm{C}\right)=[(A+T) \times 2$ $+(C+G) \times 4]-5$ (Miyada et al., 1985). This rule applies for a salt concentration of $1 \mathrm{M} \mathrm{NaCl}$. In practice, all hybridization and washing 


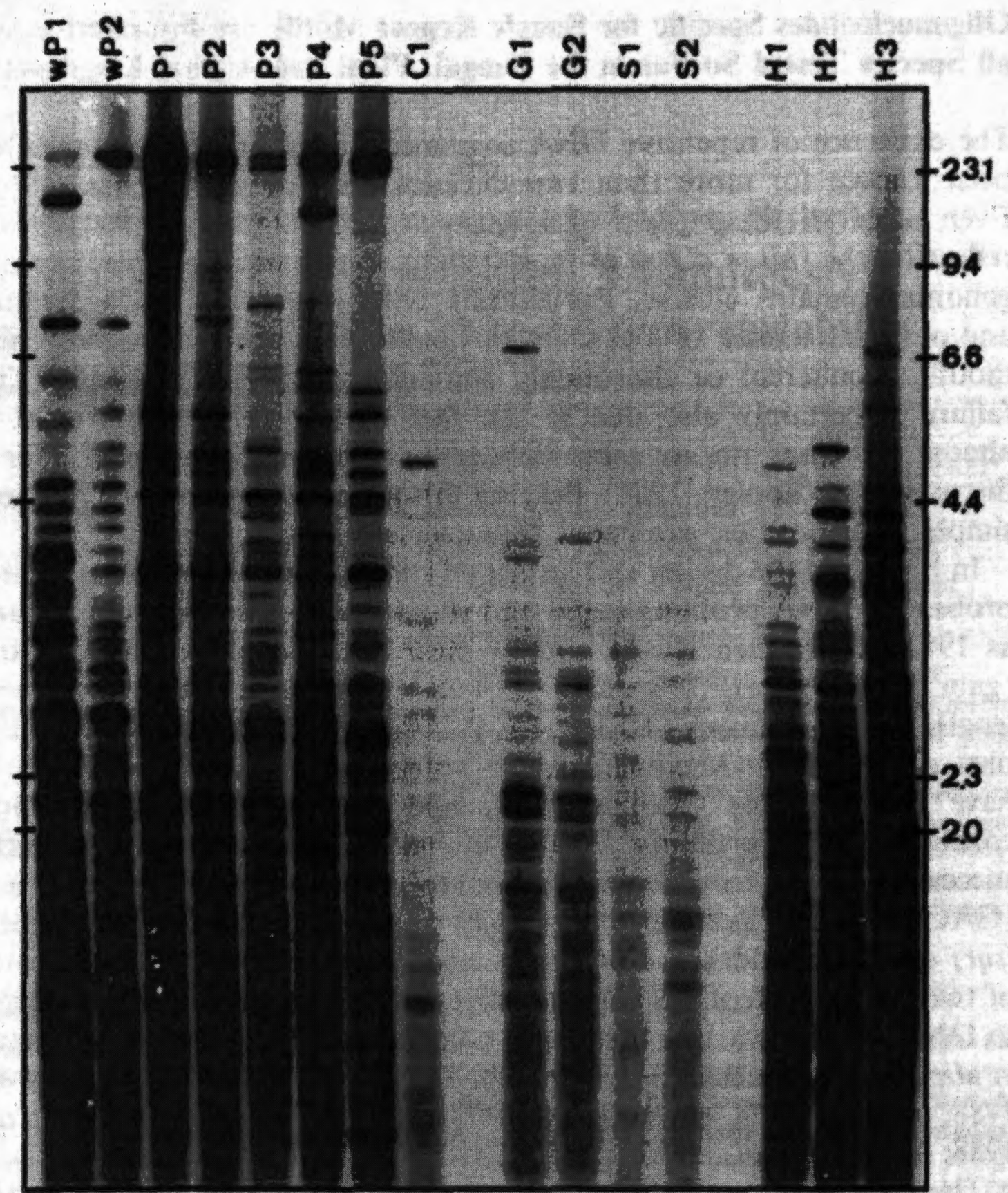

Figure 1. Oligonucleotide fingerprints as obtained with the probe (GGAT) 4 in wild boar (wP1-wP2), domestic pigs (PI-P5), camel (CI), goat (G1-G2), sheep (S1-S2) and horse (H1-H3) DNA after Hinfl digestion. DNA was prepared from peripheral blood leukocytes, digested and separated by agarose gel electrophoresis ( $0.7 \%$ in Tris-acetate buffer). The gel was dried and hybridized with the ${ }^{32} \mathrm{P}$-labeled probe under the stringent conditions described previously (Schäfer et al., 1988). Exposure was performed overnight without intensifying screens. Note the inter-individual variability in each species and the species-specific amount and distribution of the ranges of fragment lengths. Molecular weight markers are given in kilobases on the right. Approximately equal amounts of DNA have been applied with the exception of lane PI, which is overloaded. The relationships of the individuals in each species are not known. As can be inferred from our other family data in these species, they appear to include close relatives. 
Table 1. Simple repetitive oligonucleotide probes for DNA fingerprinting

\begin{tabular}{ll}
\hline Probes & Sequences \\
\hline$(\mathrm{AT})_{8}$ & atatatatatatatat \\
$(\mathrm{CA})_{8}^{*}$ & cacacacacacacaca \\
$(\mathrm{CAC})_{5}^{* 0}$ & caccaccaccaccac \\
$(\mathrm{CT})_{8}$ & ctctctctctctctct \\
$(\mathrm{CT})_{4}(\mathrm{CA})_{5}$ & ctctctctcacacacaca \\
$(\mathrm{GAA})_{6}^{* 0}$ & gaagaagagaagaagaa \\
$(\mathrm{GACA})_{4}^{\circ}$ & gacagacagacagaca \\
$(\mathrm{GATA})_{2}(\mathrm{GACA})(\mathrm{GATA})_{2}$ & gatagatagacagatagata \\
$(\mathrm{GATA})_{3}(\mathrm{GACA})_{2}$ & gatagatagatagacagaca \\
$(\mathrm{GATA})_{4}^{* 0}$ & gatagatagatagata \\
$(\mathrm{GATA})_{4.5},(\mathrm{GATA})_{5} ;(\mathrm{GATA})_{5.75}{ }^{* 0}$ & 18 mer, 20 mer, 23 mer \\
$(\mathrm{GGAT})_{4}^{\circ}$ & ggatggatggatggat \\
$(\mathrm{GGGCA})_{3}$ & gggcagggcagggca \\
$(\mathrm{TCC})_{5}^{\circ}$ & tcctcctcctcctcc \\
$(\mathrm{TTAGGG})_{3}$ & ttagggttagggttaggg \\
\hline
\end{tabular}

*complementary probe available

available also in digoxigenated form

steps are conveniently performed in a temperature range from $35^{\circ} \mathrm{C}$ to $65^{\circ} \mathrm{C}$, solely depending on the length and the base composition of the probe.

In order to give a rough overview from our previous experiences, Table 2 lists many of the fungal, plant and animal species that have so far been investigated by oligonucleotide fingerprinting. Depending on the species of interest, different oligonucleotide probes are informative for various purposes. The number of probes, harboring principally different simple repeat sequence motifs, necessary for the study of almost all eukaryotic genomes is 20 or less. It should be mentioned here that no emphasis has been laid on a systematically ordered phylogenetic compilation. In addition to individuality testing in several species, the accumulation of simple repetitive sequences on the heteromorphic sex chromosomes can at the same time be demonstrated by sex-specific hybridization patterns (Nanda et al., 1990a; see also below). Finally, in primates including man (and in several fungi) certain simple sequence motifs are associated with the nucleolus organizer regions (NORs), probably due to their accumulation in the spacer regions between the ribosomal RNA genes (Nanda et al., 1990b; Beyermann et al., unpubl. data).

Oligonucleotide Fingerprinting in Man with Special Reference to Mutation Rates, Tumors and Statistical Evaluations of Paternity Disputes

Following the initial efforts which consecutively used combinations of the (GATA) 4 and (GACA) $)_{4}$ and related "mixed" probes, optimal 
Table 2. A comprehensive list of eukaryote species fingerprinted by oligonuckeotide probes

\begin{tabular}{ll}
\hline $\begin{array}{l}\text { Species } \\
\text { investigated }\end{array}$ & $\begin{array}{l}\text { Informative probes for individualization } \\
\text { or identification*, sex chromosome status }\end{array}$ \\
\hline
\end{tabular}

Fungi

Phycomyces blakesleeanus (Zygomycetes)

Ascochyra rabiei (Ascomycetes)

Saccharomyces cerevisiae (Ascomycetes)

Penicillium janthinellum (Ascomycetes)

Penicillium citroriridae (Ascomyceles)

Penicillium chrysogenum (Ascomycetes)

Aspergillus niger (Ascomycetes)

Aspergillus flavus (Ascomycetes)

Aspergillus oryzae (Ascomycetes)

Aspergillus batatae (Ascomycetes)

Aspergillus awamorl (Ascomycetes)

Trichoderma harzianum (Ascomycetes)

Candida mallosa (Deuteromycetes)

Candida utilis (Deuteromycetes)

Plants

Coprinus comalus (Basidiomycetes)

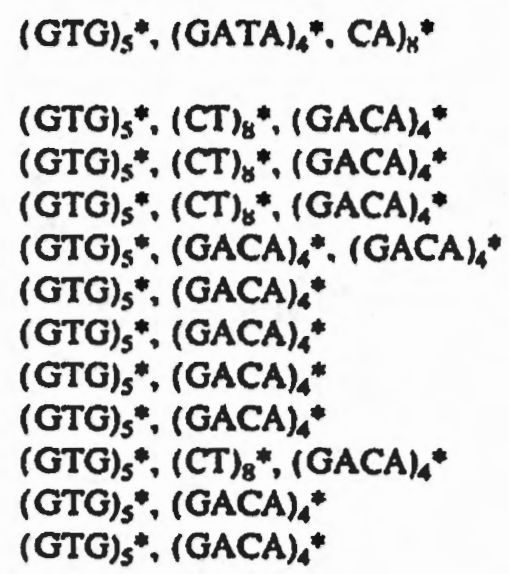

(CA)*, (GATA)*, (GTG) s*, (GACA) ${ }_{4}^{*},(\text { GATA })_{4}^{*}$ 
Table 2. (continued)

Species

investigated
Informative probes for individualization

or identification*, sex chromosome status ${ }^{+}$
Daucus carota saticus (Rosidae)

Camellia sinensis (Dilleniidae)

Brassica oleracea (Dilleniidae)

Brassica napus (Dilleniidae)

Nicotiana tabacum (Asteridae)

Nicotiana paniculata (Asteridae)

Nicottana glutinosa (Asteridae)

Nicotiana acuminata (Asteridae)

Lycopersicum esculentum (Asteridae)

Lycopersicum hirsutum (Asteridae)

Lycopersicum pimpinellifollum (Asteridae)

Lycopersicum peructanum (Asteridae)

Solanum tuberosum (Asteridae)

Helianthus annuus (Asteridae)

Lactuca sativa (Asteridae)

Petunia hybrida (Asteridae)

Silene alba (Carophyllaceac)

Arabidopsis thaliana (Brassicacaceae)

Rumex acetosella (Polygonaceae)

Beta vulgaris (Chenopodiaceae)

Beta maritima (Chenopodiaceae)

Microseris pjgmea (Asteraceae)

Animals

Microseris bigelowit (Asteraceae)

Ciliates

Stylonychia lemnae

Protozoa

Leishmania brasiliensis

Leis/mania gujanensis

Leishmania mexicana

Trypanosoma cruzi

Insects

Poccillimon tessalicus

Macrosiphum rosue

Vertebrates

Fish

Latimeria chalumnac

Poecilia reticulata

Poecilia sphenops

Poecilia velifera

Poecilia perugiae

Poecilia formosa

Poecilia latipinna

Xiphophorus maculatus

Xiphophorus helleri

Xiphophorus montezumae

Xiphophorus cortesi

Clupea harengus

Salmo trutta

Leporinus obtusidens

Leporinus elongatus

Amphibians

Bufo melanostictus

Necturus maculatus

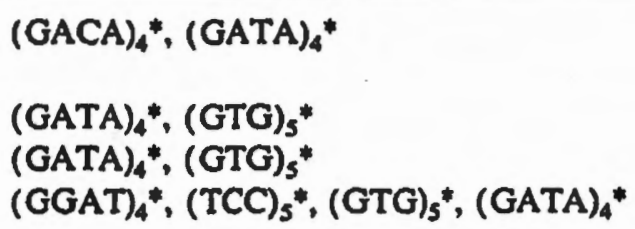

$\left(\right.$ GGAT $_{4} *,(\mathrm{GTG})_{5} *,(\mathrm{GATA})_{4}^{*}$

$(\text { GGAT) })_{4}^{*},(\text { GAA })_{6}^{*},(\text { GATA })_{4}^{*}$

$(\text { GGAT })_{4}^{*},(\text { GAA })_{6}^{*},(\text { GATA })_{4}^{*}$

$(\text { GGAT })_{4}^{*},(\text { GAA })_{6}^{*},(\text { GATA })_{4}^{*}$

$(\text { GATA })_{4}^{*},(\text { GTG })_{5}^{*},(\text { GGAT })_{4}^{*},(\text { TCC })_{5}^{*},(\text { GACA })_{4}^{*}$

$(\text { GTG })_{5}^{*},(\text { GATA })_{4}^{*}$

$(\text { GATA })_{4}^{*}$

$(\text { GTG })_{5}^{*},(\text { GATA })_{4}^{*}$

$(\text { GATA })_{4}^{*},(\text { GGAT })_{4}^{*}$

$(\mathrm{GACA})_{4}^{*},(\mathrm{GATA})_{4}^{*}$

$(\text { GACA })_{4}^{*},(\text { GATA })_{4}^{*}$

$\left(\right.$ GATA) ${ }^{*}$

$(\mathrm{CAC})_{3} *$

$(\mathrm{CAC})_{s}^{*}$

$(\mathrm{CAC})_{s}^{*}$

$(\mathrm{CAC})_{5}$

$(\mathrm{GACA})_{4}^{*},(\mathrm{GATA})_{4}^{*}$

$(\text { GATA })_{4}^{*}$

$(\mathrm{CA})_{8}{ }^{*},(\mathrm{CT})_{4}(\mathrm{CA})_{5} *$

$(\text { GGAT })_{4}^{*},(\text { GATA })_{4}^{*},(\text { GACA })_{4}^{*}$

$\left(\mathrm{GGAT}_{4}{ }^{*},(\mathrm{CA})_{8}{ }^{+}\right.$

$(\text { GGAT) })^{*},(\mathrm{CA})_{8}+$

$\left(\right.$ GGAT) $4^{*},(\text { GACA })_{4}$

$(\text { GGAT })_{4}^{*},(\text { GACA })_{4}$

$(\mathrm{GGAT})_{4}^{*},(\mathrm{GACA})_{4}^{*}$

$(\mathrm{GGAT})_{4}^{*},(\mathrm{GACA})_{4}^{*}$

(GATA) ${ }_{4}^{*}$

(GACA) *

$(\mathrm{GACA})_{4}^{*}$

(GACA $)_{4}^{*}$

$(\mathrm{GACA})_{4}^{*}$

$(\mathrm{GACA})_{4} *,(\mathrm{CA})_{8} *,(\mathrm{TCC})_{5} *$ 
Table 2. (continued)

Species

investigated
Informative probes for individualization

or identification*, sex chromosome status ${ }^{*}$

(GACA)*, (CA $)_{8}^{*}$

$(\mathrm{GACA})_{4}^{*},(\mathrm{CA})_{8} *$

$(\mathrm{TCC})_{s} *$

$(\mathrm{GACA})_{4}^{*},(\mathrm{GATA})_{4}^{*},(\mathrm{CA})_{8}^{*},(\mathrm{TCC})_{8}^{*}$

$(\text { GACA })_{4}^{+},(\text {GATA })_{4}^{+}$

$(\text { GACA })_{4}^{+},(\text {GATA })_{4}^{+},(\text {GTG })_{5}^{*}$

$(\text { GACA })_{4}+,(\text { GATA })_{4}+,(\text { GTG })_{5} *$

(GATA) $4^{*}$

(GTG) $)_{s}^{*}$

$(\text { GATA })_{4}^{*}$

Boa constrictor imperatus

Birds

Buteo buteo

Accipiter nisus

Accipiter gentilis

Nyctea scandiaca

Tinnunculus tinnunculus

Hierofalco peregrinus

Hierofalco rusticolus

Hierofalco cherrug

Hierofalco biarmicus

Bubo bubo

Milvus milous

Aquila chrysaetos

Gallus domesticus

Columba livia domestica

Phylloscopus collybila

Periparus ater

Cyanistes caeruleus

Erithacus rubecula

Fringilla coelebs

Coccothraustes coccothraustes

Pyrrhula pyrrhula

Mammals

Canis lupus familiaris

Canis lupus famillaris Sapsari

Equus p. coballus

Sus scrofa domesticus

Ontotragus megaceros

Odocoileus dichotomus (Blastoceros)

Odocolleus bezoarticus (Blastoceros)

Cervus duvauceli

Tragelaphus spekei

Bos taurus

Capra aegagrus hircus

Ovis ammon aries

Ellobius lutescens

Cletrionomys glareolus

Apodemus flavicollis

Apodemus sylvaticus

Microtus agrestis

Rattus norvegicus

Mus musculus

Cricetulus griseus $(\text { GGAT) })_{4}^{*}$

$(\text { GGAT) })^{*}$

$(\text { GGAT) })^{*}$

$($ GGAT) 4

(GGAT) *

(GACA)*

(GACA)*

(GACA) ${ }_{4}^{*}$

(GACA) $)_{4}^{*}$

(GACA)*

(GGAT) ${ }_{4}^{*}$

$(\mathrm{GACA})_{4} *(\mathrm{GGAT})_{4} *$

$(\text { GGAT })_{4}^{*},(\text { GTG })_{5}^{*},(\text { TCC })_{5}+$

$(\text { GGAT })_{4}^{*},(\mathrm{TCC})_{5}{ }^{*}$

$(\mathrm{GACA})_{4}^{*},(\mathrm{GGAT})_{4} *$

$(\text { GACA })_{4}^{*},($ GGAT) 4 *

(GACA)*, (GGAT)*

(GACA)*, (GGAT) *

$(\text { GACA })_{4}^{*},($ GGAT) $*$

$(\text { GACA })_{4}^{*},(\text { GGAT) })_{4}^{*}$

$(\text { GACA })_{4}^{*},($ GGAT) 4 *

$(\mathrm{CA})_{8}{ }^{*},(\mathrm{GTG})_{s} *$

(GTG) $)^{*}$

$(\mathrm{CA})_{8} *,\left(\right.$ GGAT) $4_{4}^{*},(\mathrm{GTG})_{5} *$

$(\mathrm{AT})_{8} *,(\mathrm{GGAT})_{4}^{*},(\mathrm{TCC})_{5}{ }^{*}$

(GTG) $)_{5}^{*}$

(GTG)*

(GTG) $)_{5}^{*}$

(GTG) $)^{*}$

(GTG) $s^{*}$

$(\text { GTG })_{5}^{*},(\text { GGAT })_{4}^{*},(C A)_{8} *$

$(\mathrm{GACA})_{4} *(\mathrm{CA})_{8} *$

$(\mathrm{GACA})_{4}{ }^{*},(\mathrm{CA})_{8}{ }^{*}$

(GACA)*

(GACA) *

(GACA)*

(GGAT) *

(GTG) $)_{5}^{*},(\text { GATA })_{4}^{*}$

$(\text { GGGCA })_{3}^{*},(\text { GATA })_{4}^{*},(\text { GACA })_{4}^{*}$

(GACA)* 
Table 2. (continued)

\begin{tabular}{ll}
\hline $\begin{array}{l}\text { Species } \\
\text { investigated }\end{array}$ & $\begin{array}{l}\text { Informative probes for individualization } \\
\text { or identification*, sex chromosome status }\end{array}$ \\
\hline $\begin{array}{l}\text { Nesokia indica } \\
\text { Nyctalus noctula }\end{array}$ & \\
Hylobates syndactylus & $(\text { GATA })_{4}$ \\
Macaca mulatta & $(\mathrm{GTG})_{5}^{*}$ \\
Aotus trivirgatus & $(\mathrm{GTG})_{5}^{*},(\mathrm{GACA})_{4}^{* \ell},(\mathrm{GATA})_{4}^{*}$ \\
Pongo pygmaeus & $(\mathrm{GACA})^{*}$ \\
Pan troglodyles & $(\mathrm{GTG})_{5}^{*},(\mathrm{GACA})_{4}^{*}$ \\
Gorilla gorilla & $(\mathrm{GTG})_{5}^{*},(\mathrm{GACA})_{4}^{*}$ \\
Homo sapiens & $(\mathrm{GTG})_{5}^{*},(\mathrm{GACA})_{4}^{*}$ \\
\hline
\end{tabular}

"sex differences depending on the population investigated

\& associated with nucleolus organizers

genetic individualization in the human was subsequently achieved in a single hybridization step using $(\mathrm{CAC})_{5}$ (Schäfer et al., 1988). Solely depending on the resolving power of the gel system used, all human individuals can be distinguished with the only exception of genetically identical, monozygotic twins. In practice one single case of questionable paternity could not be cleared up because the putative fathers were monozygotic brothers (Pöche et al., in press). The only possibility of solving such a problem would have occurred if one of the men carried a somatic mutation that the other one lacked. Using several informative probes this rare event was not encountered. So far only one case of monozygotic twins with differences in their $(\mathrm{CAC})_{s} /(\mathrm{GTG})_{s}$ fingerprints has been encountered (Hundrieser et al., unpubl. data). On the other hand, even questionable paternity cases can be solved beyond any doubt, whereas enzyme polymorphism studies alone would have had insufficient discrimination power or could have yielded false exclusions (Bender et al., 1991).

Nürnberg et al. (1989) established the somatic stability of $\left(\mathrm{CAC}_{5} /\right.$ (GTG) $)_{5}$ fingerprints in human tissues and determined the mutation rate to be 0.001 per fragment per gamete (from more than 350 meioses). Meanwhile, this rate has been confirmed further by increasing the sample size to over 1500 meioses (unpubl. data). Somatic stability and similar or even reduced mutation rates have been determined for the

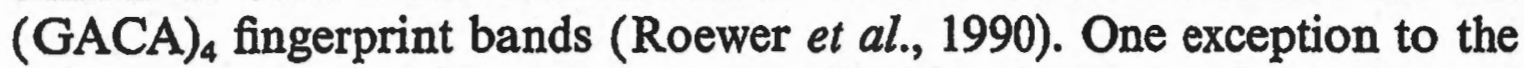
rule of somatic stability has been provided by the study of transformed tissues (Lagoda et al., 1989). Indeed, in an extended parallel fingerprint and cytogenetic study on human gliomas versus peripheral blood, $(\mathrm{CAC})_{5} /(\mathrm{GTG})_{5}$ proved to be a superior probe for the detection of genomic alterations (Nürnberg et al., in press). Changes of the constitutional patterns were observed in nearly $80 \%$ of the gliomas, and subsequent investigation using additional probes detected an additional 
$15 \%$ alterations in the fingerprints. These changed patterns mostly reflect the corresponding chromosomal aberrations seen in a majority of the cells. Concomitantly it was observed that particularly strong fingerprint bands appeared in about $30 \%$ of the gliomas when probed with independent simple repeat oligonucleotides. After digestion with several restriction enzymes that recognize unrelated target sequences, consecutive hybridizations with the $(\mathrm{CA})_{8}$ probe and a cDNA clone containing epidermal growth factor (EGF) receptor gene sequences revealed the comigration of one simple repeat band with one of the amplified EGF receptor gene fragments (Nürnberg et al., in press). Thus gene amplification events can readily be monitored by the set of simple repeat probes due to their ubiquitous distribution all over the human chromosomal complement. During the same investigation it was also noted that the telomere lengths increased during the progression of some glioma tumors as revealed by the telomere repeat probe (ttaggg) $)_{3}$. This is in contrast to the findings of Hastie et al. (1990), who described recently shortened telomeres in colon carcinomas and aged fibroblasts. In conclusion, oligonucleotide fingerprinting is a valuable asset whenever cultured cells of various sources need to be identified (Speth et al., in press).

Since it is not known which bands are allelic to one another in a complex fingerprint pattern, formal genetic models and the corresponding classical statistics cannot be used for the evaluation of multilocus fingerprints in paternity analysis. In addition, one or both of the alleles at a locus might well be hidden in the smeared signal below the 2-3 kilobase $(\mathrm{kb})$ range, which is not resolved in routine fingerprint gels. Various new statistical approaches have been worked out for calculating the probability of paternity from multilocus fingerprint profiles (for a discussion see Fimmers et al., 1990; Yassouridis and Epplen, 1991). The primary method relies on the calculation of likelihood ratios based on Bayes' theorem (Evett et al., 1989). This likelihood approach can also be adopted for use in deficiency cases (Yassouridis, in preparation). Despite quite promising results and comparatively widespread recognition - also due to good experiences with the method in practical case work - some restrictions and compromises affect the practicability of the approach of Evett et al. It is not yet known if simpler methods which depend on fewer assumptions will finally prove practicable and if they will meet the necessary standards.

\section{Advantages of the Demonstration of Genetic Individuality by Oligonucleotide Fingerprinting}

It has been repeatedly stated that oligonucleotide fingerprinting is advantageous over related methodologies for a number of reasons: (i) the constant probe quality for up to a million hybridizations from a 
single batch of chemically synthesized oligonucleotide; (ii) no need for blotting, and therefore no loss of DNA due to non-optimal transfer, by simply fixing the DNA in the dried gel matrix; (iii) the least time-consuming procedure, additionally due to short hybridization times with higher probe concentrations and limited, standardized washing steps; (iv) the possibility of repeated hybridizations of the same gel-fixed DNA - especially in comparison to filter-bound nucleic acids; (v) convenient non-radioactively labeled probes that can also be hybridized directly in the gel (Zischler et al., 1989). Above all, the most significant advantage over other fingerprint probes is the base-specific hybridization under the appropriate conditions: mismatch abrogates hybridization. Therefore, if one follows the established protocols, almost absolute reproducibility is obtained.

\section{Forensic Applications of Genetic Fingerprints}

The forensic sciences represent an immediately obvious and broad field of application for individualization techniques, i.e. analyses of stains from spots of blood and sperm, vaginal swabs, sputum, urine, hair roots, decayed tissue remains, parts of bodies, etc. (Pöche et al., 1990; Roewer et al., 1990; Sprecher et al., 1990). Oligonucleotide fingerprinting has been successfully used in actual casework including the identification of burnt bodies (Sprecher et al., in press; Pöche et al., in press). During the successful identification from the DNA of one of the burnt bodies, a remarkable phenomenon was observed that should be brought to the attention of other investigators whilst requiring further experimental clarification: informative $(\mathrm{GTG})_{5}$ fingerprints of normal intensity could be established, whereas when using the probe (GACA) ${ }_{4}$ in a rehybridization only extremely weak patterns were observed. This feature is absolutely reproducible using the DNA from the one burnt body. Upon the next hybridization with (GATA) ${ }_{4}$ the result was again negative, yet (TCC) $)_{5}$ on the other hand yielded the expected intense bands for identification. It thus appears as if the oligonucleotide probes with a high GC content were still hybridizing, whereas this was not true when the GC content was $50 \%$ or less. One working hypothesis to explain this probe hybridization behaviour relates to the possible partial denaturation of DNA into single strands under high temperatures depending on the base composition: (i) single-stranded DNA was much more amenable to degradation in the burnt tissue remains, generating at random broken short fragments, (ii) single-stranded DNA would not be cut (as efficiently) and (iii) the subsequent agarose gel electrophoretic separation of unpaired single DNA strands would not result in a distinct pattern but rather in a smeary, background-like signal. These possibilities are considered in ongoing in vitro experiments by heating 
tissues to different temperatures and demonstrating the fingerprint patterns obtained using a variety of simple repetitive oligonucleotides with different GC content. Finally, another source of artifacts has not yet received sufficient attention: the "hidden partial" phenomenon (Nürnberg and Epplen, 1989), where some sites in the genomic DNA need, for completely unknown reasons, an exorbitant amount of enzymatic activity and are not digested.

In this context Roewer et al. (1990) have recently established some general rules for oligonucleotide fingerprinting with respect to the amount and the quality of the DNA samples available, as well as the informativeness of several probes for each purpose. Because of the possibility of repeated rehybridizations, for complicated cases, including those with low amounts of degraded DNA, the results of different oligonucleotides can preferably be combined. Though the virtually absolute sensitivity of the polymerase chain reaction (PCR) cannot be reached by conventional oligonucleotide fingerprinting, the inherent and partly uncontrollable problems of PCR concerning minute contaminations are almost completely avoided. Because of the species-specific accumulation and organisation of these repetitive elements, any large scale contamination of the stain by, for example, blood from a different animal species or fungal overgrowth, can readily be sorted out by hybridizing with the panel of additional simple repeat oligonucleotides identifying the foreign additive. Almost all prokaryotic DNA contaminations would not contain any simple repetitive motifs.

\section{Variation of Simple Repeats in Clonal Vertebrates}

Questions concerning genetic identity or relatedness are being asked more and more in the different biological disciplines. In unisexual fish like Poecilia formosa (Telostei, Poeciliidae) a single genome is transmitted from mothers to daughters through several generations without genetic recombination (Monaco et al., 1984). For the apomictic breeding of the laboratory lines a single male of an ornamental black molly strain is used which gives the physiological stimulus for gynogenesis, but which does apparently not contribute to the gene pool of $P$. formosa. One of us (MScha) has been keeping two laboratory strains that had been separated for at least seven years. When the fingerprint patterns were compared between several individuals from both strains, a bandsharing rate of $80 \%$ or more was observed between the strains (depending on the restriction enzyme/probe combination). Individuals from sibships and their respective mothers show variation limited mostly to very few, truly hypervariable loci (Schartl et al., 1990; Schartl et al., submitted). These results stand in clear contrast to those of a recent study of wild populations by Turner et al. (1990), where the fingerprints 
of specimens caught at identical and at different locations were described to be comparatively variable.

\section{Heterochromatin and Sex Chromosome Evolution as Studied by Fingerprinting and in situ Hybridization Using Non-isotopically Labeled Oligonucleotide Probes}

Animal (and plant) sex chromosome evolution probably started on different occasions with a homologous pair of autosomes leading to morphologically differentiated sex chromosomes. In fishes (and reptiles) a range from poorly established to thoroughly heteromorphic gonosomes is sometimes found in closely related species. The guppy fish Poecilia reticulata is characterized by the $\mathrm{XX} / \mathrm{XY}$ sex chromosome mechanism. Yet the $Y$ chromosome can only be identified cytologically on the basis of (i) its heterochromatin staining, (ii) via its Y-chromosomally accumulted (gaca) $n$ sequences by hybridization in situ or (iii) the male-specific high molecular weight smear after electrophoretic separation and hybridization with this same probe (Nanda et al., 1990). All these recent investigations were considerably ameliorated by the fact that non-radioactively labeled oligonucleotide (digoxigenin or biotin) probes could be developed for the in situ hybridizations to metaphase chromosomes (Zischler et al., 1989). In addition, the probe (GATA) 4 reveals a Y chromosomal polymorphism in the commercially available guppy strains. In contrast, in the closely related genus Xiphophorus none of the genetically defined heterogametic situations could be verified consistently with simple repeat probes. Only particular Xiphophorus populations produced consistent sex-specific hybridization patterns with (GATA) . $^{\text {. }}$ Other poeciliid species ( $P$. sphenops var. melanistica and $P$. velifera) harbour different sex-specifically organized repeat motifs in females on the $\mathrm{W}$ chromosome (Nanda et al., in press). Thus the accumulation of various diverse simple repeats often accompanies the initial steps of sex chromosome differentiation, leading finally either to male or female heterogamety and the $\mathrm{XX} / \mathrm{XY}$ or $\mathrm{ZZ} / \mathrm{ZW}$ sex chromosome mechanism.

\section{Development of Single Copy Probes for Individual Hypervariable Loci from a $(\mathrm{CAC})_{5} /(\mathrm{GTG})_{5}$ Human Fingerprint}

Multilocus fingerprints in humans are composed of many hypervariable bands originating from different loci spread more or less evenly over the genome. Initially, evidence for dispersion originated mainly from in situ hybridization data (Zischler et al., 1989; Nanda et al., in press) and from segregation analyses in a limited number of other species (Epplen et al., unpublished). In very few species like, for example, Ephestia kuehniella only two or three chromosomal loci harbour long stretches of particular 
simple repeat motifs (Traut et al., submitted). Whether the allelic signals from one and the same locus in humans appear in the resolvable part of the complex fingerprint pattern or not depends on the multilocus probe used and length variations of the target fragments. As there is much overlap in the size range of alleles at different loci, multilocus profiles do not reveal an individual's genotype at any locus and so maintain genetic confidentiality. The main advantage of locus-specific probes is clearly the defined formal genetic model (and therefore the associated accepted statistical treatment). For other reasons we have tried several approaches to generate such locus-specific markers from the human $(\mathrm{CAC})_{s} /(\mathrm{GTG})_{s}$ fingerprint: (i) screening of a complete genomic phage library after partial Sau3AI digestion; (ii) screening of a (partial) phage library containing 3-10 kb fragments after complete MboI digestion; (iii) semispecific ligation-mediated polymerase chain reaction (PCR), which involves the ligation of adaptors to isolated $3-10 \mathrm{~kb}$ fragments followed by PCR using primers specific for the adaptor and the simple (cac/gtg) repeat (Zischler et al., 1991; Zischler et al., in preparation). Thereafter the PCR products are conveniently cloned into plasmid vectors.

A major disadvantage of the PCR approach is the comparatively time-consuming evaluation of the informativeness of the isolated probes, which has to be done by hybridization to restriction enzyme digested human DNA from different individuals. In addition, in (i) and (ii) the phages containing simple repeats often showed cloning artifacts in the prokaryotic hosts due to deletions and other complex rearrangements. Approach (iii) also involved prescreening of the clones obtained for the presence of other repetitive elements by separate dot blot hybridization with, for example, human Alu repeats and total human DNA. One of us (HZ) came up with at least four hypervariable locus probes spread over the human genome (heterozygosity rate $>90 \%$ ), several informative probes (heterozygosity $>50 \%$ ) and many clones $(25-30)$ that are less informative or contain additional repeats that confound their exact evaluation even after competition hybridizations, specific oligonucleotide syntheses and hybridizations and other procedures. The apparent evolutionary conservation of individual human hypervariable loci ranges from those found to hybridize to taxa from fish (and chicken) to primates, even under moderately stringent conditions, to no detectable conservation at all. The potential expression of the informative probes is presently being investigated at the mRNA level.

Exonic Polymorphism Versus Intronic Hypervariability: A Mixed Simple Repeat Locus in $H L A-D R B$ and Related Genes

Recently, several hypervariable, highly informative single copy loci have been described (see previous section; Nakamura et al., 1987; Jeffreys et 
al., 1989; Vergnaud, 1989; Armour et al., 1990; Vergnaud et al., 1991; Zischler et al., 1991). In part these have already proven to be useful for many purposes. Yet so far the direct comparison of highly polymorphic protein encoding genes and adjacent simple repeat sequences has been almost completely lacking. The $H L A$-locus (Klein, 1986) in man offers such a possibility: in intron II of the HLA-DRB genes, simple repetitive $(\mathrm{gt})_{\mathrm{n}} /(\mathrm{ga})_{\mathrm{m}}$ sequences border exon II (Riess et al., 1990). We therefore started to apply the polymerase chain reaction method to amplify, subclone and determine the sequence of exon II of several HLA-DRB loci including in each case the $5^{\prime}$-part of the adjacent intron. In Fig. 2 the experimental strategy is shown; by making use of the sequence information of the $H L A-D R B$ sequences several oligonucleotides were constructed to prime specifically either whole groups of related exonic sequences (e.g. $D R w 52$ ) or exclusively the genes coding for one particular serological haplotype (for experimental details see Riess et al., 1990). Two intronic primers anneal $3^{\prime}$ to the simple repeat. Being situated essentially at the same target sequence, they vary only in their lengths, and one of them included a convenient restriction enzyme cutting site not present in the original intronic sequence.

From initial analysis on sequencing gels, it was found that a cluster of three to four bands was always amplified from one template DNA due

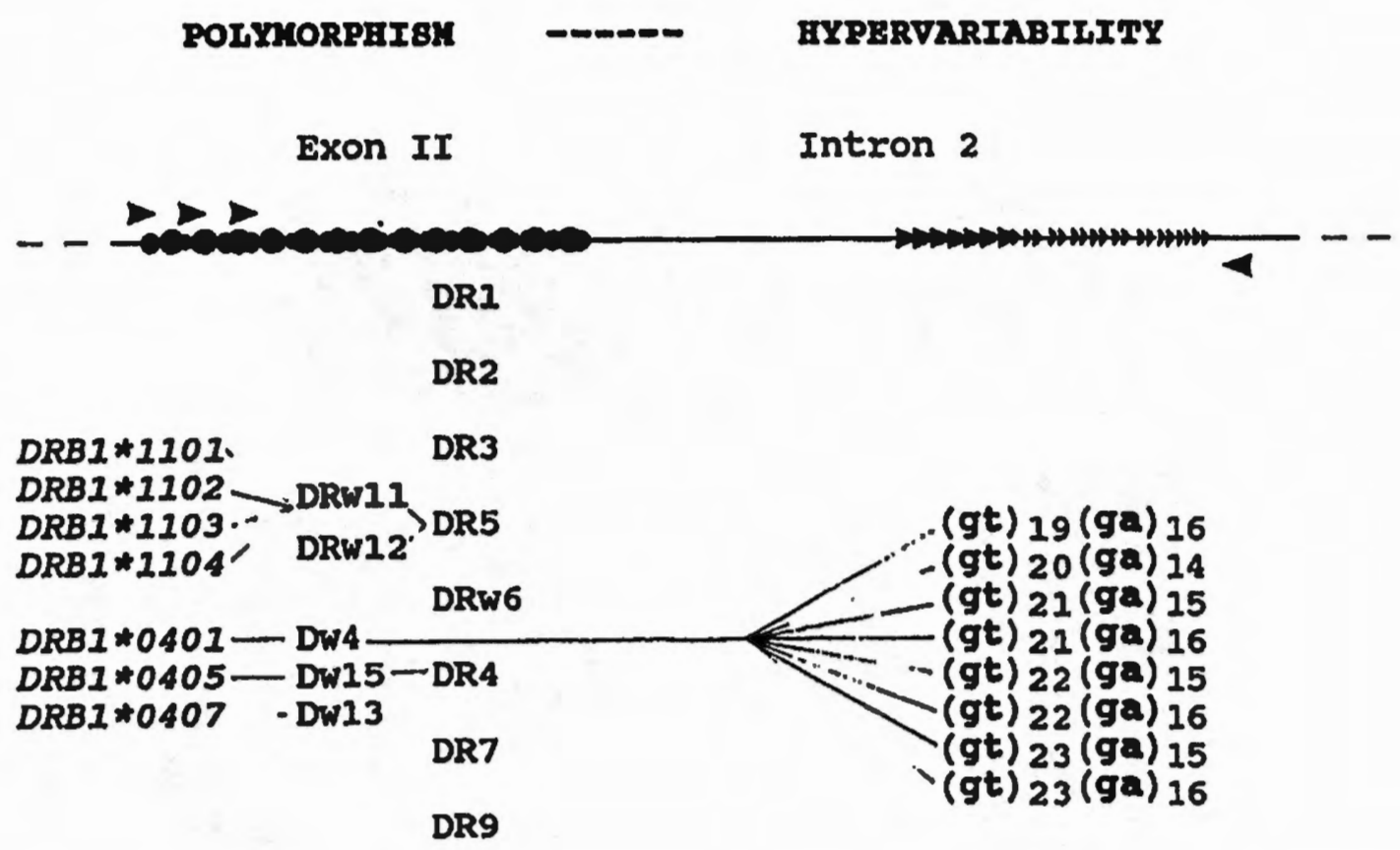

DRw10

Figure 2. Protein polymorphism versus DNA hypervariability. First a DNA fragment is amplified that contains exon II and the simple repeat locus in the adjacent intron. Amplification primers are symbolized as arrowheads. After cloning, sequence analysis yields from one end protein encoding sequence and from the other the composition of the simple repeat. The serological HLA-DR types can be split into subtypes (DR4-Dw4, Dw15, Dw13 etc.). One exonic sequence (e.g. DRB $1 * 0401$ ) can be accompanied by many different simple repeats. 
to slipping of the Taq polymerase in the simple repeat region. It has been shown previously by electroblot hybridization and sequence determination that these amplified exon-intron region clusters are inherited according to Mendelian laws (Riess et al., 1990). For example, among ten randomly sampled, unrelated individuals typed serologically as $D R 4$ and subtype $D w 4$ (all $H L A-D R B 1 * 0401$ exonic sequences), the basic simple repeat structure is completely maintained. Variatons occur exclusively in the numbers of the dinucleotide unit copy numbers: In the (gt) stretch, $n$ ranges from $19-23$, whereas $m$ in (ga) $)_{m}$ ranges from 14-16. In the $D R w 52$ group, a more complex basic repeat structure is found: $(\mathrm{gt})_{\mathrm{n}}(\mathrm{ga})_{\mathrm{m}} \mathrm{ca}(\mathrm{ga})_{3}\left[\mathrm{ca}(\mathrm{ga})_{3}\right]$. Here, there is abundant variation in the $(\mathrm{gt})_{\mathrm{n}}$ sequence, but significantly less in the first $(\mathrm{ga})_{\mathrm{m}}$ stretch. Table 3 summarizes the group-specific architecture of the simple repeat blocks including data from a baboon (Papio hamadryas, Paha) and cattle (Bos taurus, $B o t a)$. Throughout this table only one intermediately long version is given from several (between 1 and 12) investigated for each $H L A-D R B$ gene sequence: invariably the stretch commences with $(\mathrm{gt})_{n}$, whereby $n$ ranges from 6 in a $D R 1$ pseudogene intron to 26 in a $D R B 1 * 1401$ individual. This simple dinucleotide organization of the $5^{\prime}$ stretch is interrupted only in two categories: $D R w 53$ pseudogenes and $D R B 4$ introns. On the other hand the following $(\mathrm{ga})_{\mathrm{m}}$ stretches of dinucleotides exhibit numerous deviations, depending on the $H L A-D R$ gene investigated. Simple $(\mathrm{ga})_{\mathrm{m}}$ repeats appear in $D R B 1 * 0401$, in the pseudogene associated repeats and in the only baboon sequence. Group-specific simple repeat organization could also be demonstrated across species barriers, for example in a parallel study on Bota-DR intronic simple repeats from cattle (H. Ammer, W. Schwaiger, C. Kammerbauer, and J. T. Epplen, submitted). We were particularly surprised by the repeat composition in the Bota-DR sequence: the exon exhibits $95 \%$ homology to the protein domains of the $D R w 52$ supergroup and, also, the intronic repeat is virtually indistinguishable from its human counterparts ( $H$. Ammer, W. Schwaiger, C. Kammerbauer, and J. T. Epplen, unpubl. data; genomic Bota-DR DNA clone obtained from Groenen et al., 1990; there were several differences in the sequences obtained from the same isolate in independent analyses in two laboratories). Attempts to perform a phylogenetic analysis on the simple repeats for comparison with the results obtained from the $H L A$ protein sequences are hampered by the inability of the available alignment programs to perform (meaningful) simple sequence alignments. If the alignments are done "by eye", i.e. introducing gaps to separate the pure $(\mathrm{gt})_{\mathrm{n}}$ and $(\mathrm{ga})_{\mathrm{m}}$ repeats, and thereafter one applies the Felsenstein programs (1989), then more closely related groups are found to cluster together (Epplen, unpublished). Attempts to establish respective algorithms for "meaningful" alignments of simple sequences are presently being evaluated (Zucker et al., in preparation). 
Table 3. Intronic simple $(\mathrm{gt})_{\mathfrak{a}}(\mathrm{ga})_{\mathrm{m}}$ repeats in DRB and related genes

\begin{tabular}{|c|c|c|}
\hline $\begin{array}{l}\text { "DRB" allele/ } \\
\text { No. individ./ } \\
\text { RFLP }\end{array}$ & $\begin{array}{l}\text { Total } \\
\text { repeat } \\
\text { length }\end{array}$ & Repeat composition \\
\hline HLA-DRB1 $* 0101 / 2$ & $44(g t)_{15}$ & aa $(\mathrm{ga})_{1} \mathrm{aa}(\mathrm{ga})_{4}$ \\
\hline $\begin{array}{l}\text { HLA-DRB1 } * 0301 / 7 / 3 b \\
\text { HLA-DRB1*0301/1/3a } \\
\text { HLA-DRB } * 0302 / 1 / 3 c\end{array}$ & $\begin{array}{l}64(g t)_{15} \\
66(g t)_{17} \\
68(g t)_{19}\end{array}$ & $\begin{array}{l}(\mathrm{ga})_{7} \mathrm{ca}(\mathrm{ga})_{3} \mathrm{ca}(\mathrm{ga})_{5} \\
(\mathrm{ga})_{6} \mathrm{ca}(\mathrm{ga})_{3} \mathrm{ca}(\mathrm{ga})_{5} \\
(\mathrm{ga})_{6} \mathrm{ca}(\mathrm{ga})_{3} \mathrm{ca}(\mathrm{ga})_{4}\end{array}$ \\
\hline $\begin{array}{l}\text { HLA-DRB } 1 * 0401 / 12 \\
\text { HLA-DRB } * 0404 / 1 \\
\text { HLA-DRB } 1 * 0405 / 4 \\
\text { HLA-DRB } 1 * 0407 / 1\end{array}$ & $\begin{array}{l}74(\mathrm{gt})_{22} \\
90(\mathrm{gt})_{22} \\
70(\mathrm{gt})_{19} \\
76(\mathrm{gt})_{21}\end{array}$ & $\begin{array}{l}(\mathrm{ga})_{15} \\
(\mathrm{ga})_{23} \\
(\mathrm{ga})_{16} \\
(\mathrm{ga})_{17}\end{array}$ \\
\hline HLA-DRB $1 * 0801 / 4$ & $62(g t)_{18}$ & $(\mathrm{ga})_{7} \mathrm{ca}(\mathrm{ga})_{5}$ \\
\hline HLA-DRB1 $* 1001 / 1$ & $48(g t)_{16}$ & $(\mathrm{ga})_{8}$ \\
\hline $\begin{array}{l}\text { HLA-DRB } 1 * 1101 / 2 / 5 c \\
\text { HLA-DRB } 1 * 1102 / 1 / 5 c \\
\text { HLA-DRB } 1 * 1103 / 3 / 5 c \\
\text { HLA-DRB } 1 * 1104 / 1 / 5 c \\
\text { HLA-DRB } 1 * 1104 / 1 / 5 c\end{array}$ & $\begin{array}{l}74(\mathrm{gt})_{20} \\
72(\mathrm{gt})_{22} \\
88(\mathrm{gt})_{22} \\
76(\mathrm{gt})_{22} \\
80(\mathrm{gt})_{25}\end{array}$ & $\begin{array}{l}(\mathrm{ga})_{6} \mathrm{ca}(\mathrm{ga})_{3} \mathrm{ct}(\mathrm{ga})_{6} \\
(\mathrm{ga})_{3} \mathrm{ca}(\mathrm{ga})_{3} \mathrm{ca}(\mathrm{ga})_{6} \\
(\mathrm{ga})_{11} \mathrm{ca}(\mathrm{ga})_{3} \mathrm{ca}(\mathrm{ga})_{6} \\
(\mathrm{ga})_{5} \mathrm{ca}(\mathrm{ga})_{3} \mathrm{ca}(\mathrm{ga})_{6} \\
(\mathrm{ga})_{5} \mathrm{ca}(\mathrm{ga})_{3} \mathrm{ca}(\mathrm{ga})_{5}\end{array}$ \\
\hline $\begin{array}{l}\text { HLA-DRB } 1 * 1301 / 1 / 6 b \\
\text { HLA-DRB } 1 * 1301 / 3 / 6 a \\
\text { HLA-DRB } 1 * 1301 / 1\end{array}$ & $\begin{array}{l}76(g t)_{17} \\
88(g t)_{23} \\
92(g t)_{25}\end{array}$ & $\begin{array}{l}(\mathrm{ga})_{10} \mathrm{ca}(\mathrm{ga})_{3} \mathrm{cagc}(\mathrm{ga})_{5} \\
(\mathrm{ga})_{10} \mathrm{ca}(\mathrm{ga})_{3} \mathrm{ca}(\mathrm{ga})_{6} \\
(\mathrm{ga})_{10} \mathrm{ca}(\mathrm{ga})_{3} \mathrm{ca}(\mathrm{ga})_{6}\end{array}$ \\
\hline HLA-DRB $1 * 1401 / 1$ & $88(g t)_{26}$ & $(\mathrm{ga})_{11} \mathrm{ca}(\mathrm{ga})_{6}$ \\
\hline HLA-DRB $1 * 1501 / 7$ & $82(g t)_{19}$ & $(\mathrm{ga})_{5} \mathrm{ca}(\mathrm{ga})_{4} \mathrm{ca}(\mathrm{ga})_{3} \mathrm{ggaa}(\mathrm{ga})_{6}$ \\
\hline HLA-DRB4*0101/2 & $70(g t)_{2} a t(g t)_{11}$ & $(\mathrm{ga})_{12} \mathrm{ca}(\mathrm{ga})_{1} \mathrm{ggaa}(\mathrm{ga})_{5}$ \\
\hline HLA-DRB $5 * 0101 / 9$ & $74(g t)_{21}$ & $(\mathrm{ga})_{5} \mathrm{ggaa}(\mathrm{ga})_{4} \mathrm{ca}(\mathrm{ga})_{2} \mathrm{gg}(\mathrm{ga})_{1}$ \\
\hline $\begin{array}{l}\text { HLA-DR1 } \psi / 3 \\
\text { HLA-DR2 } \psi / 3 \\
\text { IHLA-DR4 } \psi / 2 \\
\text { HLA-DR7 } \psi / 1\end{array}$ & $\begin{array}{l}32(\mathrm{gt})_{6} \\
48(\mathrm{gt})_{13} \\
37(\mathrm{gt})_{2} \mathrm{tt}(\mathrm{gt})_{3} \\
35(\mathrm{gt})_{2} \mathrm{tt}(\mathrm{gt})_{3}\end{array}$ & $\begin{array}{l}(\mathrm{ga})_{10} \\
(\mathrm{ga})_{11} \\
\mathrm{t}(\mathrm{ga})_{5} \\
\mathrm{t}(\mathrm{ga})_{5}\end{array}$ \\
\hline Paha/1 & $42(g t)_{14}$ & $(g a)_{7}$ \\
\hline Bota*/1 & $86(g t)_{20}$ & $(\mathrm{ga})_{9} \mathrm{ca}(\mathrm{ga})_{2} \mathrm{ca}(\mathrm{ga})_{2}\left[\mathrm{ca}(\mathrm{ga})_{2}\right]_{2}$ \\
\hline
\end{tabular}

*Ammer, corrected sequence; but see Groenen et al. (1990)

Finally, apart from these purely evolutionary aspects, our studies also aim at a better understanding of the significance of the invariantly present $(\mathrm{gt})_{\mathrm{n}}(\mathrm{ga})_{m}$ simple repeat locus, since the latter has been identified in such diverse vertebrate species. Is this ubiquitous presence just a mere coincidence? Does the repeat represent a DNase hypersensitive site? Do particular proteins bind to this DNA region? Are there secondary structures like, for example, Z DNA (Rich et al., 1984) or $\mathrm{H}$ DNA (Mirkin et al., 1987) possible in this part of the intron? 
In an initial attempt to make use of the information provided by this simple repeat locus, rheumatoid arthritis (RA) patients were also included in the panel of the aforementioned $D R B 1 * 0401$ cohort. RA has been found previously to be associated with $H L A-D R 4$, especially, for example, with the $D R 4 D w 4$ subtype. In the limited number of probands tested, the structure and the lengths of the simple repeats of RA patients and healthy control individuals did not differ. In principle the same result was found for multiple sclerosis (MS) patients, a disease which is associated with the serologically determined $H L A-D R 2$ haplotype. The comparison of the $D R 2$ gene adjacent simple repeats from healthy donors and MS patients revealed neither particular sequence lengths nor configurations (Epplen et al., unpublished).

\section{Future Prospects}

It is now well established that loci containing tandem simple repeat sequences are a practically unrestricted source of highly informative markers in eukaryote genomes. Therefore they appear to be the tools for a diverse range of applications. In addition to their already recognized utility for individualization, the simple repeat sequences will have an especially major impact in large scale mapping projects, for example in interrelating and ordering cosmids and yeast artificial chromosomes from genomic libraries. One particularly interesting development concerns a veritable hotspot of recombination in the chicken genome, which has initially been identified using the (GAA), simple repeat probe: more than $80 \%$ of the length alleles in true offspring cannot be matched to either the paternal or to the maternal genotype (Nanda et al., submitted). Meanwhile, from this simple repeat locus an adjacent single copy probe has been isolated by semispecific PCR (see above) as well as genomic phage clones, with the aid of which a detailed, targeted analysis will be performed. But apart from these problemcentred considerations there are also solid grounds to expect, in due course, major breakthroughs in the quest for the actual significance of these enigmatic simple tandem elements. It has been proposed that simple repetitive sequences have weak enhancer-like activity in viral expression systems. Certainly, at least in vitro, they are able to occur in special confirmations, i.e. secondary structures, depending on the purine/pyrimidine composition. Yet whether the outcome will be that they represent merely junk and jumble from the evolutionary past or that they bear present day function(s), only the results of diligent experimentation and insightful interpretation in a broad and open conceptual framework will tell. 


\section{Acknowledgements}

We thank the many collaborating colleagues who contributed information on the informativeness of simple repeat probes in various species not available to us. This work was supported by the VW-Stiftung and the DFG (Ep 7/5-1 and Ep 7/6-1). The simple repetitive oligonucleotides and locus-specific probes are subject to patent applications. Commercial enquiries should be directed to Fresenius AG, W-6370 Oberursel, Germany.

\section{References}

Ali, S., Müller, C. R., and Epplen, J. T. (1986) DNA fingerprinting by oligonucleotides specific for simple repeats. Hum. Genet. 74: 239-243.

Armour, J. A. L. (1990) Systematic cloning of human minisatellites from ordered array charomid libraries. Genomics 8: 501-512.

Arnemann, J., Schmidtke, J., Epplen, J. T., Kuhn, H.-J., and Kaumanns, W. (1989) DNA fingerprinting for paternity and maternity in group 0 Cayo Santiago-derived Rhesus monkeys at the German Primate Center: results of a pilot study. Puerto Rico Health Sci. J. 8: $181-184$.

Bender, K., Kasulke, D., Mayerova, A., Hummel, K., Weidinger, S., Epplen, J. T., and Wienker, T. (1991) New mutation versus exclusion at the PI locus: a multifaceted approach in a problematical paternity case. Hum. Hered. 814 41: 1-11.

Beyermann, B., Nürnberg, P., Weihe, A., Meixner, M., Epplen, J. T., and Börner, T. (1991) Fingerprinting plant genomes with oligonucleotide probes specific for simple repetitive DNA sequences. Theor. Appl. Genet. (in press).

Britten, R. J., and Kohne, D. A. (1968) Repeated sequences in DNA. Science 161: 529-540.

Buitkamp, J., Ammer, H., and Geldermann, H. (1991) DNA fingerprinting in domestic animal species, Electrophoresis 12: 169-174.

Buitkamp, J., Kühn, C., Zischler, H., Epplen, J. T., and Geldermann, H. (1991) DNA fingerprinting in cattle using oligonucleotide probes. Anim. Genet. (in press).

Epplen, J. T. (1988) On simple repeated GATA/GACA sequences: a critical reappraisal. J. Hered. 79: 409-417.

Epplen, J. T., Kammerbauer, C., Steimle, V., Zischler, H., Albert, E., Andreas, A., Hala, K., Nanda, I., Schmid, M., Riess, O., and Weising, K. (1989) Methodology and application of oligonucleotide fingerprinting including characterization of individual hypervariable loci. In: Radola, B. J. (ed.) Electrophoresis Forum '89. Bode-Verlag, München, pp. 175-186.

Epplen, J. T., McCarrey, J. R., Sutou, S., and Ohno, S. (1982) Base sequence of a cloned snake W-chromosome DNA fragment and identification of a male-specific putative mRNA in the mouse. Proc. Natl. Acad. Sci. USA 79: 3798-3802.

Epplen, J. T., Studer, R., and McLaren, A. (1988) Heterogeneity in the Sxr (sex-reversal) locus of the mouse as revealed by synthetic GAT/CA probes. Genet. Res. 51: 239-246.

Evett, I. W., Werrett, D. J., and Buckleton, J. S. (1989) Paternity calculations from DNA multilocus profiles. J. Forensic Sci. Soc. 29: 249-254.

Felsenstein, J. (1988) Phylogenies from molecular sequences: inference and reliability. Ann. Rev. Genet. 22: 521-565.

Fimmers, R., Epplen, J. T., Schneider, P. M., and Baur, M. P. (1990) Likelihood calculations in paternity testing on the basis of DNA-fingerprints. Adv. Forensic Haemogenet. 3: 14-16.

Groenen, M. A. M., van der Poel, J. J., R. J. M. Dijkhof, and Giphart, M. J. (1990) The nucleotide sequence of bovine MHC class II $D Q B$ and $D R B$ genes. Immunogenet, 31: $37-44$.

Hastie, N. D., Demster, M., Dunlop, M. G., Thompson, A. M., Green, D. K., Allshire, R. C. (1990) Telomere reduction in human colorectal carcinoma and with ageing. Nature 346: 866-868.

Jeffreys, A. F., Wilson, V., and Thein, S. L. (1985a) Hypervariable "minisatellite" regions in human DNA. Nature 316: 67-73.

Jeffreys, A. F., Wilson, V., and Thein, S. L. (1985b) Individual-specific "fingerprints" of human DNA. Nature 316: 76-79.

Jeffreys, A. F., Royle, N. J., Wilson, V., and Wong, Z. (1988) Spontaneous mutation rates to new length alleles at tandem repetitive hypervariable loci in human DNA. Nature 332: 278-281. 
Klein, J. (1986) Natural History of the Major Histocompatibility Complex. Wiley, New York. Lagoda, P. J. L., Seitz, G., Epplen, J. T., and Issinger, O.-G. (1989) Increased detectability of somatic changes in the DNA after probing with "synthetic" and "genome-derived" hypervariable multilocus probes. Hum. Genet. 84: 35-40.

McLaren, A., Simpson, E., Epplen, J. T., Studer, R., Koopmann, P., Evans, E. P., and Burgoyne, P. S. (1988) Location of the genes controlling H-Y antigen expression and testis determination on the mouse $\mathrm{Y}$ chromosome. Proc. Natl. Acad. Sci. USA 85: 6442-6445.

Miyada, C. G., Reyes, A. A., Studencki, A. B., and Wallace, R. B. (1985) Methods of oligonucleotide hybridization. Proc. Natl. Acad. Sci. USA 82: 2890-2894.

Monaco, P. J., Rasch, E. M., and Balsano, J. S. (1984) Apomictic reproduction in the Amazon molly, Poecilia formosa, and its triploid hybrids. In: Turner, B. J. (ed.) Evolutionary Genetics of Fishes. Plenum Press, New York, pp. 311-328.

Nakamura, Y., Leppert, M., O’Connell, P., Wolff, R., Holm, T., Culver, M., Martin, C., Fujimoto, E., Hoff, M., Kumlin, M., and White, R. (1987) Variable number of tandem repeat (VNTR) markers for human gene mapping. Science 235: 1616-1622.

Mirkin, S. M., Lyamichev, V. I., Drushlyak, K. N., Dobrynin, V. N., Filippov, S. A., and Frank-Kamenetskii, M. D. (1987) DNA H form requires a homopurine-homopyrimidine mirror repeat. Nature 330: 495-497.

Nanda, I., Neitzel, H., Sperling, K., Studer, R., and Epplen, J. T. (1988) Simple GAT/CA repeats characterize the $\mathrm{X}$ chromosomal heterochromatin of Microtus agrestis, European field vole (Rodentia, Cricetidae). Chromosoma 96: 213-219.

Nanda, I., Deubelbeiss, C., Guttenbach, M., Epplen, J. T., and Schmid, M. (1990b) Heterogeneities in the distribution of $(\mathrm{GACA})_{\mathrm{n}}$ simple repeats in the karyotypes of primates and mouse. Hum. Genet. 85: 187-194.

Nanda, I., Feichtinger, W., Schmid, M., Schröder, J. H., Zischler, H., and Epplen, J. T. (1990a) Simple repetitive sequences are associated with differentiation of the sex chromosomes in the guppy fish. J. Mol. Evol. 30: 456-462.

Nanda, I., Schartl, M., Feichtinger, W., Epplen, J. T., and Schmid, M. (1990) Early stages of sex chromosome differentiation in fish as analyzed by simple repetitive DNA sequences. Chromosoma (in press).

Nanda, I., Schmid, M., and Epplen, J. T. (1991) In silu hybridization of nonradioactive oligonucleotide probes to chromosomes. In: Adolph, K. W. (ed.) Advanced Techniques in Chromosome Research. Marcel Decker, New York pp. 117-134.

Nürnberg, P., and Epplen, J. T. (1989) "Hidden Partials" - a cautionary note. Fingerprint News 1(4) 11-12.

Nürnberg, P. Roewer, L., Neitzel, H., Sperling, K., Pöpperl, A., Hundrieser, J., Pöche, H., Epplen, C., Zischler, H., and Epplen, J. T. (1989) DNA fingerprinting with the oligonucleotide probe $(\mathrm{CAC})_{s} /(\mathrm{GTG})_{s}$ : somatic stability and germline mutatations. Hum. Genet. 84: 75-78.

Nürnberg, P., Zischler, H., Fuhrmann, E., Thiel, G., Losanova, T., Kinzel, D., Nisch, G., Witkowski, R., and Epplen, J. T. (1991) Co-amplification of simple repetitive DNA fingerprint fragments and the EGF receptor gene in human gliomas. Genes Chromosomes Cancer 3 (in press).

Pöche, H., Peters, C., Wrobel, G., Schneider, V., and Epplen, J. T. (1991) Determining consanguinity by oligonucleotide fingerprinting with $(\mathrm{GTG})_{5} /(\mathrm{CAC})_{5}$. Electrophoresis (in press).

Pöche, H., Wrobel, G., Schneider, V., and Epplen, J. T. (1991) The identification of a charred body by oligonucleotide fingerprinting with the (GTG), probe. DNA Technol. Legal Med.

Pöche, H., Wrobel, G., Schneider, V., and Epplen, J. T. (1990) DNA fingerprinting with simple repetitive oligonucleotide probes in forensic medicine. Adv. Forensic Haemogenet. 3: 122-124.

Pöche, H., Wrobel, G., Schneider, V., and Epplen, J. T. (1990) Oligonucleotid-Fingerprinting mit (GTG) 5 und (GACA) 4 für die Zuordnung von Leichenteilen. Archiv Kriminologie 186: 37-42.

Rich, A., Nordheim, A., and Wang, A. H. Z. (1984) The chemistry and biology of left handed Z DNA. Ann. Rev. Biochem. 53: 791-846.

Riess, O., Kammerbauer, C., Roewer, L., Steimle, V., Andreas, A., Albert, E., Nagai, T., and Epplen, J. T. (1990) Hypervariability of intronic simple $(\mathrm{gt})_{\mathfrak{n}}(\mathrm{ga})_{\mathrm{m}}$ repeats in $H L A-D R B I$ genes. Immunogenet. 32: 110-116. 
Roewer, L., Nürnberg, P., Fuhrmann, E., Rose, M., Prokop, O., and Epplen, J. T. (1990) Stain analysis using oligonucleotide probes specific for simple repetitive DNA sequences. Forensic Sci. Internatl. 47: 59-70.

Roewer, L., Rose, M., Semm, K., Correns, A., Epplen, J. T. (1989) Typisierung gelagerter, hämolysierter Blutproben durch "DNA-Fingerprinting". Archiv Kriminologie 184: 103-107.

Schäfer, R., Zischler, H., Birsner, U., Becker, A., and Epplen, J. T. (1988) Optimized oligonucleotide probes for DNA fingerprinting. Electrophoresis 9: 369-374.

Schartl, M., Nanda, I., Schlupp, I., Parzefall, J., Schmid, M., and Epplen, J. T. (1990) Genetic variation in the clonal vertebrate Poecilia formosa is limited to truly hypervariable loci. Fingerprint New's 2(4): 22-24.

Speth, C., Epplen, F. T., and Oberbäumer (1991) DNA fingerprinting with oligonucleotides can differentiate cell lines derived from the same tumor. In Vitro (in press).

Sprecher, W., Berg, S., and Epplen, J. T. (1990) Identifikation von Blutproben und foetalem Gewebe durch genetisches Fingerprinting. Archiv Kriminologie 185: 44-51.

Sprecher, W., Kampmann, H., Epplen, J. T., and Gross, W. (1991) Idenifizierung einer Brandleiche mit Hilfe des DNA-Fingerprinting. Rechtsmedizin (in press).

Tautz, D. (1989) Hypervariability of simple sequences as a general source for polymorphic DNA markers. Nucleic Acids Res. 17: 6463-6471.

Turner, B. J., Elder, J. F., Laughlin, T. F., and Davis, W. P. (1990) Genetic variation in clonal vertebrates detected by simple-sequence DNA fingerprinting. Proc. Natl. Acad. Sci. USA 87: $5653-5657$.

Vergnaud, G. (1989) Polymers of random short oligonucleotides detect polymorphic loci in the human genome. Nucleic Acids Res. 17: 7623-7630.

Vergnaud, G., Mariat, D., Zoroastro, M., and Lauthier, V. (1991) Synthetic tandem repeats of short oligonucleotides can detect single and multiple polymorphic loci. Electrophoresis 12: $134-140$.

Vogel, W., Steinbach, P., Djalali, M., Mehnert, K., Ali, S., and Epplen, J. T. (1988) Chromosome 9 of Ellobius lutescens is the X chromosome. Chromosoma 96: 112-118.

Weising, K., Fiala, B., Ramloch, K., Kahl, G., and Epplen, J. T. (1990) Oligonucleotide fingerprinting in angiosperms. Fingerprint News 2: 5-8.

Weising, K., Weigand, F., Driesel, A. J., Kahl, G., Zischler, H., and Epplen, J. T. (1989) Polymorphic simple GATA/GACA repeats in plant genomes. Nucleic Acids Res. 17: 10128 [1 page].

Weising, K., Beyermann, B., Ramser, J., and Kahl, G. (1991) Plant DNA fingerprinting with radioactive and digoxigenated oligonucleotide probes complementary to simple repetitive DNA sequences. Electrophoresis 12: 159-168.

Weising, K., Ramser, J., Kaemmer, Kahl, G., and Epplen, J. T. (1991) Oligonucleotide fingerprinting in plants and fungi. In: Burke, T., Dolf, G., Jeffreys, A. J, and Wolff, R. (eds) DNA fingerprinting: Approaches and Applications. Birkhäuser, Basel. pp. 312-319. (This volume).

Yassouridis, A., and Epplen, J. T. (1991) On paternity determination from multilocus DNA profiles. Electrophoresis 12: 221-225.

Zischler, H., Hinkkanen, A., and Studer, R. (1991) Oligonucleotide fingerprinting with $(\mathrm{CAC})_{5}$ : Non-radioactive in-gel hybridization and isolation of hypervariable loci. Electrophoresis 12: 141-145.

Zischler, H., Nanda, I., Schäfer, R., Schmid, M., and Epplen, J. T. (1989) Digoxigenated oligonucleotide probes specific for simple repeats in DNA fingerprinting and hybridization in situ. Hum. Genet. 82: 227-233. 